\title{
Detection of open water dynamics with ENVISAT ASAR in support of land surface modelling at high latitudes
}

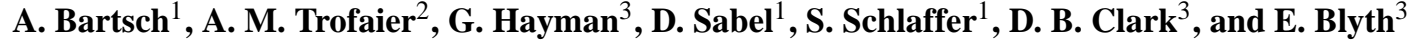 \\ ${ }^{1}$ Vienna University of Technology, Institute of Photogrammetry and Remote Sensing (IPF), \\ 1040 Vienna, Austria \\ ${ }^{2}$ Scott Polar Research Institute, University of Cambridge, Cambridge, CB2 1ER, UK \\ ${ }^{3}$ Centre for Ecology and Hydrology, Wallingford, Oxfordshire, OX10 8BB, UK
}

Correspondence to: A. Bartsch (annett.bartsch@tuwien.ac.at)

Received: 22 July 2011 - Published in Biogeosciences Discuss.: 12 August 2011

Revised: 29 November 2011 - Accepted: 23 January 2012 - Published: 8 February 2012

\begin{abstract}
Wetlands are generally accepted as being the largest but least well quantified single source of methane $\left(\mathrm{CH}_{4}\right)$. The extent of wetland or inundation is a key factor controlling methane emissions, both in nature and in the parameterisations used in large-scale land surface and climate models. Satellite-derived datasets of wetland extent are available on the global scale, but the resolution is rather coarse $(>25 \mathrm{~km})$. The purpose of the present study is to assess the capability of active microwave sensors to derive inundation dynamics for use in land surface and climate models of the boreal and tundra environments. The focus is on synthetic aperture radar (SAR) operating in C-band since, among microwave systems, it has comparably high spatial resolution and data availability, and long-term continuity is expected.

C-band data from ENVISAT ASAR (Advanced SAR) operating in wide swath mode ( $150 \mathrm{~m}$ resolution) were investigated and an automated detection procedure for deriving open water fraction has been developed. More than 4000 samples (single acquisitions tiled onto $0.5^{\circ}$ grid cells) have been analysed for July and August in 2007 and 2008 for a study region in Western Siberia. Simple classification algorithms were applied and found to be robust when the water surface was smooth. Modification of input parameters results in differences below $1 \%$ open water fraction. The major issue to address was the frequent occurrence of waves due to wind and precipitation, which reduces the separability of the water class from other land cover classes. Statistical measures of the backscatter distribution were applied in order to retrieve suitable classification data. The Pearson correlation between each sample dataset and a location specific representation of the bimodal distribution was used. On average
\end{abstract}

only $40 \%$ of acquisitions allow a separation of the open water class. Although satellite data are available every $2-3$ days over the Western Siberian study region, the irregular acquisition intervals and periods of unsuitable weather suggest that an update interval of 10 days is more realistic for this domain. SAR data availability is currently limited. Future satellite missions, however, which aim for operational services (such as Sentinel-1 with its C-band SAR instrument), may provide the basis for inundation monitoring for land surface and climate modelling applications.

\section{Introduction}

Wetlands and inundated areas are important features of many landscapes because of their roles in hydrological and biogeochemical cycles. Although the global annual source strength of $\mathrm{CH}_{4}$ is relatively well constrained (Denman et al., 2007), wetlands are generally accepted as being the largest but least well quantified single source of $\mathrm{CH}_{4}$, with emission estimates ranging from $100 \mathrm{Tg} \mathrm{yr}^{-1}$ (Wuebbles and Hayhoe, 2002) to $231 \mathrm{Tg} \mathrm{yr}^{-1}$ (Mikaloff Fletcher et al., 2004). Current emissions of methane from the wetlands and lakes of the Boreal region contribute much less than the tropical wetlands to the global wetland methane emissions: Walter et al. (2001) calculate that only $25 \%$ of the wetlands emissions come from wetlands north of $30^{\circ}$ North. However, due to the greater warming expected over high latitudes, they might increase faster and by a large amount than emissions from tropical regions. Northern high latitude wetland ecosystems are also of concern because of their potential to turn from a 
carbon sink to a net carbon source. Large parts are underlain by perennially frozen ground and a total of $1672 \mathrm{Pg}$ of soil carbon is estimated to be stored in northern permafrost regions (Schuur et al., 2008).

There is currently considerable interest in modelling methane emissions from wetlands and peatlands on regional and global scales (e.g. Wania et al., 2009a,b; Petrescu et al., 2010; Ringeval et al., 2010, 2011; Riley et al., 2011; Hodson et al., 2011). Riley et al. (2011) present an overview of the various biogeochemical processes involved in methane generation and the challenges of representing these processes in large-scale model applications. The land surface models used in these studies typically operate with a gridbox size of $0.5^{\circ}$ to $1.0^{\circ}$ or even larger, and use relatively simple parameterisations of methane emissions from wetlands based on key hydrological and biogeochemical variables. The key hydrological variable is the extent of the methane-producing wetland or inundated area (and its dynamics). The dynamics of inundation are also of interest in modelling studies of hydrological processes including the generation of runoff and flooding (e.g. Dadson et al., 2010). These modelling communities require observations of inundation to contribute to the evaluation of model simulated results and sometimes to serve as inputs to their models.

The wetland maps of Matthews and Fung (1987) and the Global Lakes and Wetlands Database of Lehner and Döll (2004) have often been used to study wetlands and other water bodies. These datasets provide global information on extent and types but do not include temporal dynamics. Satellite data have been shown to be of great value for the monitoring of wetlands (Davidson and Finlayson, 2007), with applications ranging from identification of aquatic vegetation to inundation dynamics. Different type of sensors can be employed at different scales. Continental to global monitoring requires a specific acquisition strategy, including regular temporal coverage at the highest sampling frequency possible in order to capture important dynamics such as precipitation- or snowmelt-induced flooding with timescales of hours to days. There is always a trade-off between spatial detail and sampling interval. The best sampling is achieved using microwave sensors which are cloud and illumination independent. Passive as well as active sensors have been shown to be applicable. Passive (SSMI) and active microwave (ERS C-band scatterometer) information has been combined with medium resolution optical data (AVHRR) for a global representation of inundation dynamics (Prigent et al., 2001, 2007). A combination of a Ku-Band scatterometer (Seawinds on QuikScat) and a passive instrument (AMSR-E) has also been shown to be suitable for detection of inundation dynamics over Siberia (Schroeder et al., 2010). Satellite lifetime is limited, what constraints the suitability for regular monitoring. Seawinds provided ten years of global data coverage but stopped operation in 2009 (Bartsch, 2010). AMSR-E acquired data 2002 - October 2011, the ERS scatterometers 1991 - July 2011.
The information retrieved from these global data has rather coarse spatial resolution ( $>25 \mathrm{~km}$ resolution), but this resolution has been sufficient for use in large-scale or global modelling studies of methane emissions (e.g. Ringeval et al., 2010) which, as noted earlier, also use a coarse grid. The modelling studies of Ringeval et al. $(2010,2011)$ and Riley et al. (2011) have all defined the wetland fraction using the global Earth Observation product of Prigent et al. (2007), which gives the area of wetland on a monthly timescale. As highlighted by Riley et al. (2011), Prigent et al. (2007) acknowledged that their product may not capture small, isolated water bodies in otherwise unsaturated areas (i.e. small fractional inundations of less than $10 \%$ cover).

Medium resolution satellite data, which are used for land cover maps (such as from MODIS, $500 \mathrm{~m}$ and MERIS, $300 \mathrm{~m}$ ), generally have low accuracy for high latitude environments, since, for example, tundra ponds are mostly below the resolution of the satellite data (Bartsch et al., 2008; Frey and Smith, 2007). Synthetic aperture radars (SARs) operating in ScanSAR mode (e.g. ENVISAT ASAR Wide Swath, $150 \mathrm{~m}$ ) have shown to be applicable for efficient and accurate mapping of water bodies at high latitudes (Bartsch et al., 2008). The clear advantage of using SAR is its capability to resolve smaller water bodies. This also provides a potential new dataset to validate global products. From a modelling perspective, the high resolution product needs to be almost complete in space and time (similar sampling) for the domain of interest if it is to be used as a driving dataset. The question addressed in this study is whether archived ScanSAR data are suitable for mapping inundation dynamics in tundra and boreal environments. The issues which need to be considered are (i) the typically irregular acquisition intervals, (ii) the constraints arising from the frequency used for the satellite measurements, (iii) classification methods and (iv) data management issues which arise from the chosen resolution and location of the area of interest. These issues have been investigated in this paper using ENVISAT ASAR wide swath data over a selected site in northern Eurasia. Uncertainties are quantified and discussed with respect to use in climate models and future satellite data availability.

\section{Material, methods and study site}

Permanent and seasonal inundation are surface phenomena which can be mapped by means of active microwave sensors. The incident radar beam is reflected by smooth water surfaces away from the sensor. This specular reflection results in low backscatter values which can thus be associated with water pixels (e.g. applied in Bartsch et al., 2008; Matgen et al., 2011). This behaviour is very distinct from other land cover classes, although low backscatter may also result from (i) the melting of snow and ice surfaces and (ii) radar shadow caused by steep terrain when viewed by side-looking sensors. Wave action on the water surface can increase the 
roughness and hence the backscatter signals to those of the surrounding land surface, depending on wavelength.

The majority of SAR data currently available for civil use has been acquired by C-band instruments (ERS, Radarsat, ENVISAT ASAR). Continuation of these records is assured because of the future plans of the European Space Agency (ESA) with respect to the Sentinel series of satellites (Attema et al., 2007; launch 2013 onwards at time of writing, www.esa.int). These kinds of sensors are attractive for climate research applications for which long time records are required. The wavelength is between $5-6 \mathrm{~cm}$, which means that even moderate wind action on the water surface can impede the specular reflection. Longer wavelengths such as L-band $(>20 \mathrm{~cm}$ ) would be preferable but their availability is limited at present, as well as in the near future. A further problem related to the use of C-band radar is the very limited penetration of the signal through emerging vegetation, for example along lake shores. Backscatter can also increase considerably when open water bodies start to freeze (e.g. Duguay et al., 2002).

Inundation is generally more extensive over flat terrain. The region of interest for this study is the West Siberian Lowland, which is a test region of the ESA STSE ALANISMethane project (http://www.alanis-methane.info). This region lies outside of glaciated terrain and radar shadow of the spaceborne remote sensing measurements is not expected. The similarity of the backscatter return from open water to that from melting seasonal snow and the different backscatter behavior of lakes in winter (due to ice cover) do however need to be accounted for. This can be addressed by using auxiliary data, e.g. information on snowmelt timing from other satellite products (Bartsch et al., 2009). For the purpose of this study, the analysis was limited to the summer months (July and August) and data from two consecutive years (2007 and 2008) were used.

A domain within the West Siberian Lowland was investigated, spanning from $68-73^{\circ}$ East and $63-69^{\circ}$ North. This domain was selected because of data availability (see Fig. 1) and the fact that the domain includes part of the largest peatland of the world (Keddy and Fraser, 2005). Atmospheric methane variations over the summer from year to year have been reported from ENVISAT SCIAMACHY data for this region (Schneising et al., 2011). The chosen domain excludes large parts of the Ob River and its floodplain, where complications from water waves were expected to be common. Furthermore, in the context of methane modelling, flooded river valleys can also be excluded as they are not expected to emit methane (Ringeval et al., 2010). While the focus of this study is on other areas, a small part of the $\mathrm{Ob}$ River floodplain was also included to enable full characterzation of the inundation dynamics within this environment.

As a first step, the previously tested method of simple thresholding (Bartsch et al., 2008) is applied for the different environments (flood plain and surrounding wetlands). The chosen domain comprises the boreal peatland as well as tundra with thermokarst ponds. The applicability of a universal threshold is tested in a number of sensitivity analyses. The problem of wave action is specifically addressed by time series analyses and comparison with meteorological data.

\subsection{ENVISAT ASAR Wide Swath data}

The Advanced Synthetic Aperture Radar (ASAR) instrument onboard the ESA's ENVISAT platform is a C-Band (centre frequency at $5.331 \mathrm{GHz}$ ) sensor that can operate in different modes of varying spatial and temporal resolution. In Wide Swath mode (WS), the instrument has a spatial resolution of $150 \mathrm{~m}$

WS data are only acquired on request, restricting their availability in general to archived material. Figure 1 shows the data coverage for higher latitudes of the Northern Hemisphere. Data were almost exclusively taken in HH (horizontal emitted and horizontal received) polarisation. A minimum of five acquisitions per month have been acquired for the summers of 2007 and 2008 for the domain of interest. The ENVISAT ASAR WS data are distributed via the ESA rolling archive at Level $1 \mathrm{~b}$. These data require preprocessing before the actual inundation classification can be made. This is done using the IPF's SAR Geophysical Retrieval Toolbox (SGRT), which is a scripting chain developed in house that calls the commercial SARscape or the free NEST software, allowing for the automatisation of the entire preprocessing procedure. Radiometric calibration and geocoding follow the Range-Doppler approach. The backscatter coefficient $\left(\sigma^{0}\right)$ is modelled as a function of the local incidence angle and is expressed in units of decibel $(\mathrm{dB})$. The ASAR WS data are adjusted to a reference incidence angle of $30^{\circ}$ (Sabel et al., 2011).

The northern location of the domain and the large amount of data required need to be taken into consideration for the processing and database setup. Oversampling needs to be avoided so as to reduce storage needs. All data were therefore geocoded to a polar stereographic projection. The projection chosen was the conformal conic type used by the National Snow and Ice Data Center (NSIDC) in the United States for polar datasets.

The surface water fraction is eventually derived for $0.5^{\circ} \mathrm{x}$ $0.5^{\circ}$ grid cells, which is broadly comprarable with the spatial resolution of land surface and climate models. Only data from scenes which cover complete grid cells were considered for further analysis. The classification results are aggregated to this grid size.

\subsection{Inundation mapping}

The backscatter value distribution of a SAR image over lakeabundant terrain is of a bimodal nature. This is the result of diffusive (surroundings) and specular (water bodies) reflection. Diffusive scatter is the dominant mode if the water fraction is below approximately $50 \%$, which is expected 

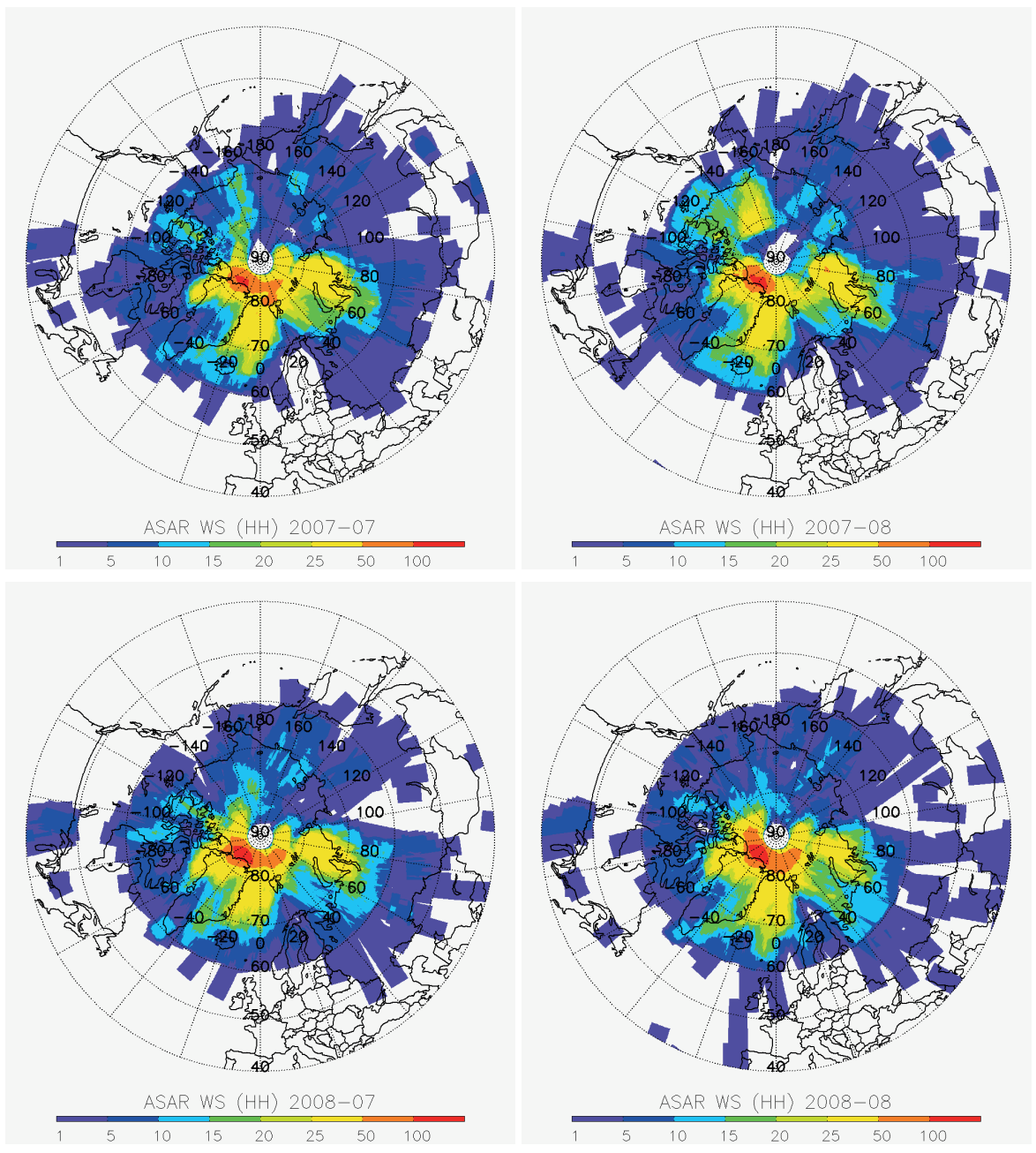

Fig. 1. ASAR Wide Swath data availability (number of scenes per month) for HH polarisation at high latitudes: July and August $2007 / 2008$.

over the region of interest. Therefore, a straightforward classification procedure for open water mapping can be established by setting a simple threshold value. Any normalized backscatter value that falls below this threshold is attributed to specular reflection and hence is classified as an open water body. Alternative methods consider (i) flooding below vegetation, what can be studied by using L-band SAR and optical data, and (ii) the random forest approach (Schroeder et al., 2010; Whitcomb et al., 2009). Changes in the roughness of the water result in changes in the maximum of the water peak and the minimum between the peaks. Adaptive approaches describe the mode (backscatter distribution) of water as Gamma-distributed, which can serve as input for classification algorithms. The overlap of the two modes/landcover types (larger values than threshold) can then be integrated via region growing (Matgen et al., 2011).
The threshold value between the modes was found to be approximately $-14 \mathrm{~dB}$ in the case of normalization of $\sigma_{0}$ to $30^{\circ}$ in tundra (Bartsch et al., 2009). This value was tested in the automated classification procedure. A Gaussian function was fitted to the backscatter value distribution for further verification of the empirically determined threshold. It is approximately within 3 standard deviations of the mean of the dominant mode. Figure 2a shows a normalized image scene and histogram of the WS data. The water bodies can be clearly distinguished from their surroundings. In this case $\mu_{\mathrm{dm}}-3 \sigma_{\mathrm{dm}}=-14.4 \mathrm{~dB}$, where $\mu_{\mathrm{dm}}$ and $\sigma_{\mathrm{dm}}$ are the mean and the standard deviation of the dominant mode, respectively.

The maximum frequency of the dominant mode occurs at higher backscatter values for taiga than for tundra (Fig. 2) due to the typical higher contribution of vegetation to the backscatter. The backscatter distribution for non-water surfaces was relatively stable over time compared to the water 
a)
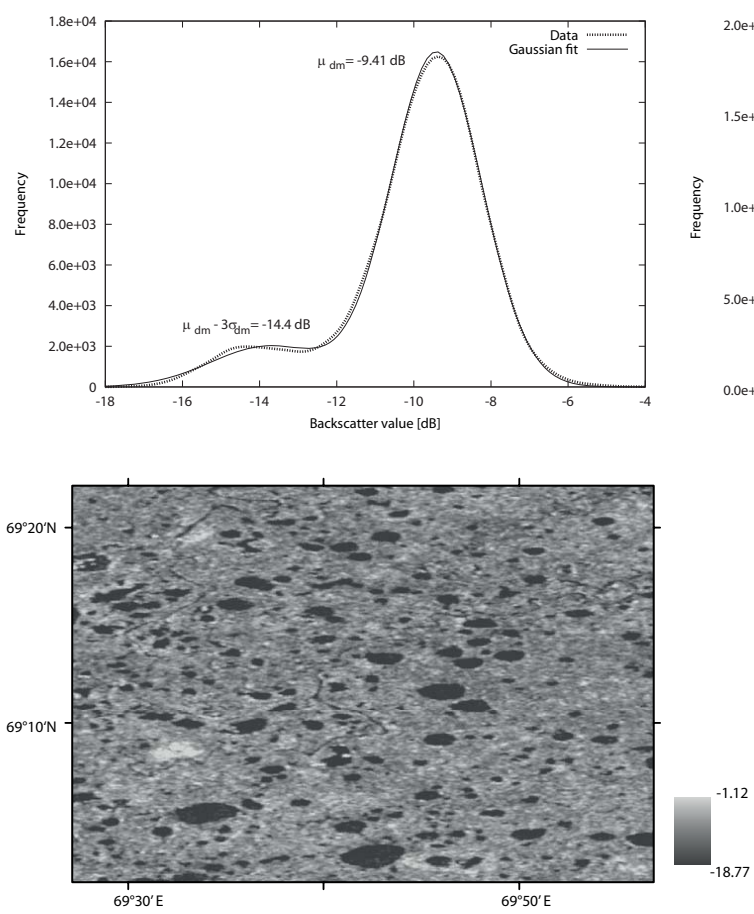

b)
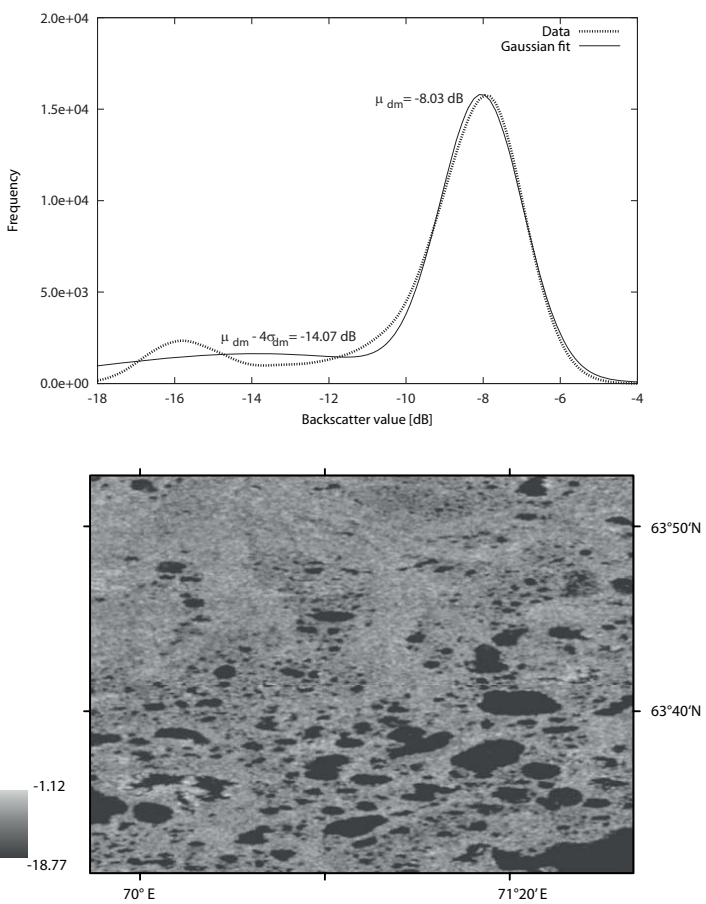

Fig. 2. Examples from summer 2007: backscatter value distribution and corresponding ASAR WS backscatter images (dB) for (a) tundra (20 August 2007) and (b) taiga (12 July 2007).

surfaces represented in the minor mode (Fig. 3). Wind and rain events increase the roughness considerably which results in the loss of the bimodal distribution and thus separability of the land cover classes. The overlap of the water backscatter signal with that from surrounding land cover is generally larger for tundra than for boreal environments. Previous analyses have demonstrated classification accuracies of $\kappa$ greater than 0.8 in the tundra-taiga transition zone (Bartsch et al., 2009).

Other thresholds were tested in order to assess the impact of the predefinition of a universal threshold for separation of water surfaces from all other land cover classes. It was assumed that values below the defined backscatter limit corresponded to specular reflection from open, calm water surfaces, outside of mountainous regions, during snow-free periods and without glaciation. More crucial however is the higher backscatter, which may correspond to mixed pixel response along the shorelines. This has been assessed by increasing the threshold to $-13 \mathrm{~dB}$ and $-12 \mathrm{~dB}$.

\subsection{Derivation of dynamics}

The number of scenes during the two summer months varies between 20 and 30. This reduces the available samples from one every two/three days to approximately one scene per week.
A test for the presence of the bimodal distribution was necessary as a preprocessing step in order to account for roughness variation and loss of separability. A location specific reference distribution has been derived for each $0.5^{\circ} \times 0.5^{\circ}$ grid cell. It is extracted from the acquisition with the maximum water fraction within the time series. The Pearson correlation between this reference and the backscatter distribution of each scene with full coverage was calculated. Positive correlations indicated separability of the water class.

\section{Results}

The maximum water fraction per $0.5^{\circ} \times 0.5^{\circ}$ grid cell reached $35 \%$ in some areas of the chosen domain but in general was below $10 \%$ (Fig. 4). Large variations of open water extent occurred in the region of the Ob Estuary, but also at some locations within the tundra region. Thermokarst lakes overflow in early summer and slowly drain through the season and/or vegetation emerges. This can be seen in Fig. 5 which also demonstrates the persistence of lake ice on large lakes well into the summer. More than 2300 samples (single scenes distributed over 133 cells; areas with coastal overlap were excluded) were used for threshold testing and the results are shown in Fig. 6. $95 \%$ of samples showed an increase of water fraction of less than 0.07 when the threshold was increased by $2 \mathrm{~dB}$ (Fig. 6a). There is a linear relationship 

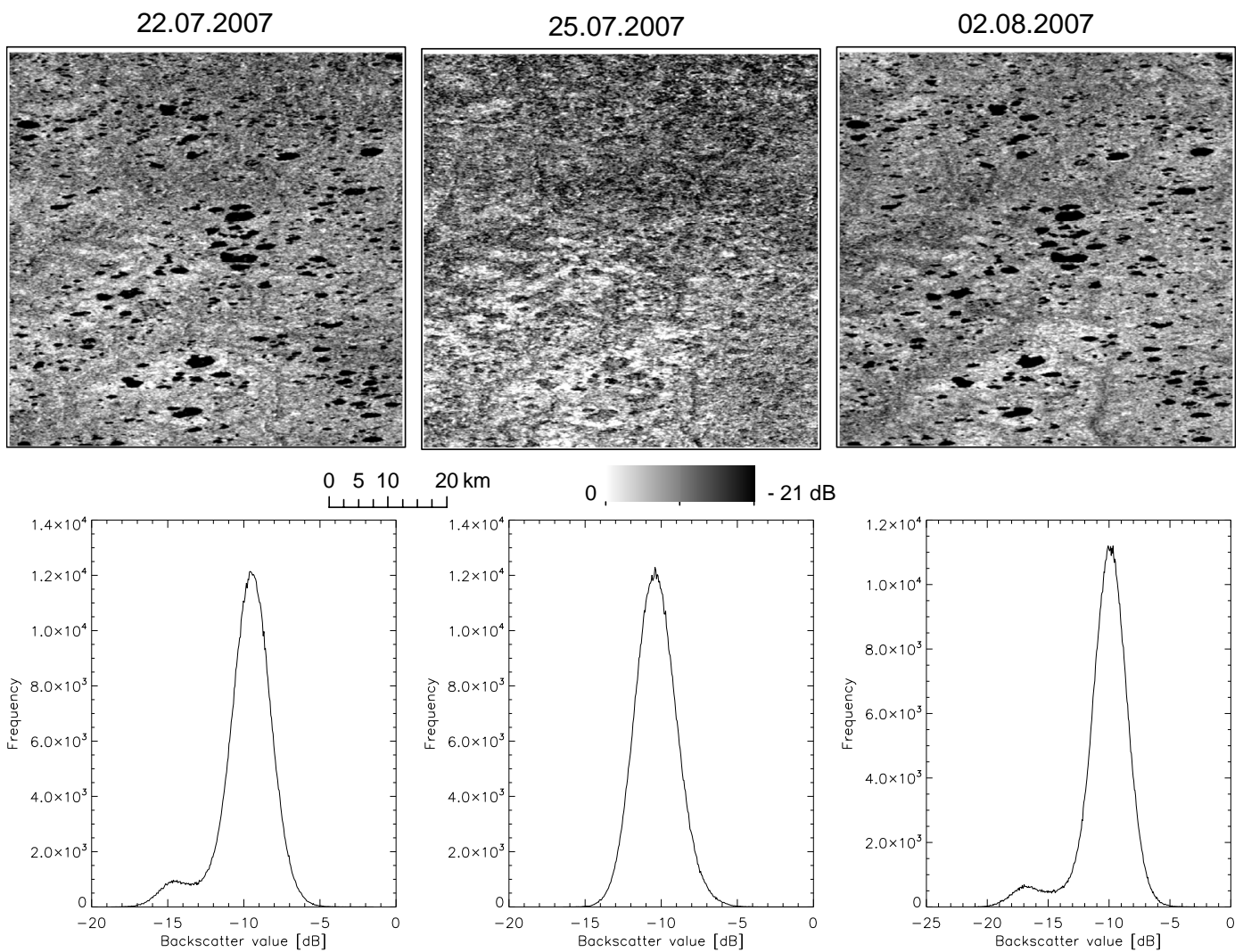

Fig. 3. Backscatter time series showing loss of bimodal distribution over tundra: top normalized backscatter images, bottom: histograms of backscatter distribution $[\mathrm{dB}]$. All images cover an indeitcal area.

between the increase in the water fraction and the threshold value (Fig. 6b). An increase of $2 \mathrm{~dB}$ results in a change in water fraction that is approximately twice as large as that for a $1 \mathrm{~dB}$ increase. The majority of the additional water fraction could be attributed to lake shores, as seen in Fig. $6 \mathrm{c}$ for an example from the tundra region.

Figure 7 shows the water fraction for example areas in both boreal (taiga) and tundra environments. Distinctive decreases during short periods can be attributed to the effects of wave action and precipitation, as discussed below. A bimodal distribution is only available for on average $40 \%$ (range 20 to $80 \%$ ) of the acquisitions for areas with indundation fraction above $5 \%$.

There are no meteorological stations with wind records in the WMO network in the selected domain. The closest station is at Salehard $\left(66.53^{\circ} \mathrm{N}, 66.53^{\circ} \mathrm{E}\right)$, west of the $\mathrm{Ob}$ estuary near to the Ob River and ASAR data were processed for the corresponding $0.5^{\circ}$ which lies outside the main study area (distance $1.5^{\circ}$ ). The water fraction in this area is also expected to be affected by wave action on the river. Wind speed data are available every three hours and the wind measurements closest in time (06:00 a.m. and 03:00 p.m.) to the acquisition time of ASAR data were extracted together with daily precipitation. These data are also shown in Fig. 7a. In this cell the maximum water fraction is approximately $23 \%$. High wind speed and precipitation are often found at times when when the estimated water fraction decreases sharply (with decreases of $50 \%$ and above). The relationship between these decreases and weather is likely partly obscured by the fact that the weather data do not refer to the exact time of ASAR acquisition and a single weather station is used to represent a $0.5^{\circ}$ square. Figures $7 \mathrm{~b}$ and 8 show that these weather-related decreases in the estimated water fraction often affect many cells at the same time, reflecting the large scale nature of the weather systems. The periods of unsuitable weather can exceed the theoretical weekly interval of data availability (scenes with bimodal distribution), suggesting that a 10-day period represents the minimum update interval achievable in this area.

Grid cells with a maximum water fraction above $10 \%$ exhibit different absolute values and dynamics for the tundra, taiga and floodplain, as seen in Fig. 9. In the tundra, the open water fraction increases by up to $3 \%$ in 2007 and decreases by a similar amount in 2008 (Fig. 9a and d). This may relate to the seasonality of lake ice. Very few grid cells have a large amount of lakes in the taiga area (Fig. 9c and f) and although 


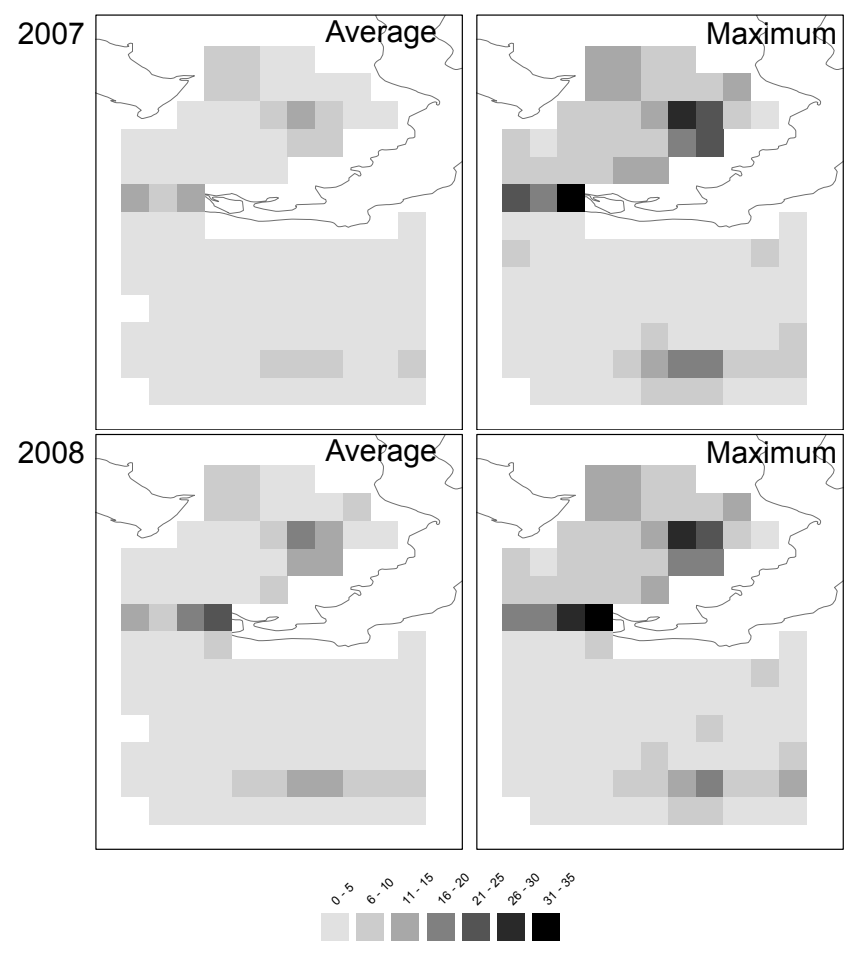

Fig. 4. Water fraction maps (in \%) from ASAR Wide Swath in July/August 2007 and 2008: (left) average and (right) maximum.

there are small variations during the summer and between years these are again small. A clear evolution over the summer and in both years is only seen along the $\mathrm{Ob}$ floodplain and estuary (Fig. 9b and e) where the inundated area steadily decreases after the spring snowmelt maximum.

\section{Discussion}

The present study tested the use of an empirical universal threshold with C-band SAR. The characteristic bimodal distribution in regions with open water mixed with other land cover is similar for both tundra and taiga environments. The threshold lies within 3 to 4 standard deviations (Gaussian fit) of the main mode. The impact of an increase of the threshold is very low with up to $0.15 \%$ for a $1 \mathrm{~dB}$ increase, and $0.25 \%$ for $2 \mathrm{~dB}$. This may be significant for applications where the exact borders of inundation are of interest, but was less important in this study which aimed to develop an efficient detection method for use across large regions.

Having suitable weather conditions is more important than the details of the classification approach since the derived water fraction often decreased by more than $50 \%$ when the weather was unsettled. It was not easy to explore this relationship because of the very sparse nature of the meteorological network in the study area. Further, the available weather data are not frequent enough to quantify conditions at the time of satellite acquisition and are limited to a single location. Nevertheless, the impact was clearly visible in the classified datasets. Pre-selection of the satellite dataset is required so as to avoid unsuitable weather. This could be done by using meteorological data that are representative of the acquisition time and area, but these are not available for many regions. Backscatter statistics were applied instead. The existence of a bimodal distribution was the major requirement when active microwave data alone were used. This could therefore be used as an indicator in regions with a sufficient open water fraction. A further constraint was the possible presence of ice on larger lakes until well into July, which is an increasingly important factor the further north one goes.

The observed magnitude of inundation fraction agrees with previous analyses with coarser sensors. The study by Schroeder et al. (2010) which covered the Spring to the end of July also reports fractions below $30 \%$ for the chosen domain. Apart from the Ob floodplain, no changes over time were reported by Papa et al. (2008), including none in the Yamal peninsula. The SAR analyses in the present study showed that this region was characterized by seasonal changes that overlap with the dynamics of thermokarst lakes. Satellite data are often used to show long-term surface water variations (over the study area e.g. Smith et al., 2004). The SAR results (Fig. 5) suggest that the seasonal dynamics of inundation must be considered in any analysis of long-term changes in surface water or permafrost degradation.

The present study was undertaken as part of a project that aims to use Earth Observation data to evaluate (and in some cases drive) estimates of methane emissions from a land surface model, the Joint UK Land Environment Simulator (JULES; Best et al., 2011; Clark et al., 2011). The question arises as to the accuracy required from the Earth Observation data if they are to be used for model evaluation and driving. Wetland emissions of methane in JULES follow the parameterisation developed by Gedney et al. (2004), in which the methane emissions from wetlands scale linearly with the wetland fraction. Gedney et al. (2004) assumed that only the fraction of the grid box where the water table was at or above the surface resulted in net emission of $\mathrm{CH}_{4}$, otherwise methanotrophic bacteria in the aerobic soil completely oxidise all the $\mathrm{CH}_{4}$ produced by the methanogenic bacteria. The methane-producing area calculated by and required by JULES is thus the inundated area that can be determined from e.g. ASAR. As such there is no minimum or threshold wetland fraction that would need to be detected by the satellite, but there is clearly a value below which the emission flux would be insignificant in terms of its effect on atmospheric methane concentrations. Alternatively, atmospheric measurements potentially provide a constraint on the minimum wetland fraction that should be represented in a wetland product. Gerilowski et al. (2011) are developing a successor to the SCIAMACHY instrument - the methane mapper (MAMAP). They considered a number of potential sources, including wetlands, which could be monitored by 


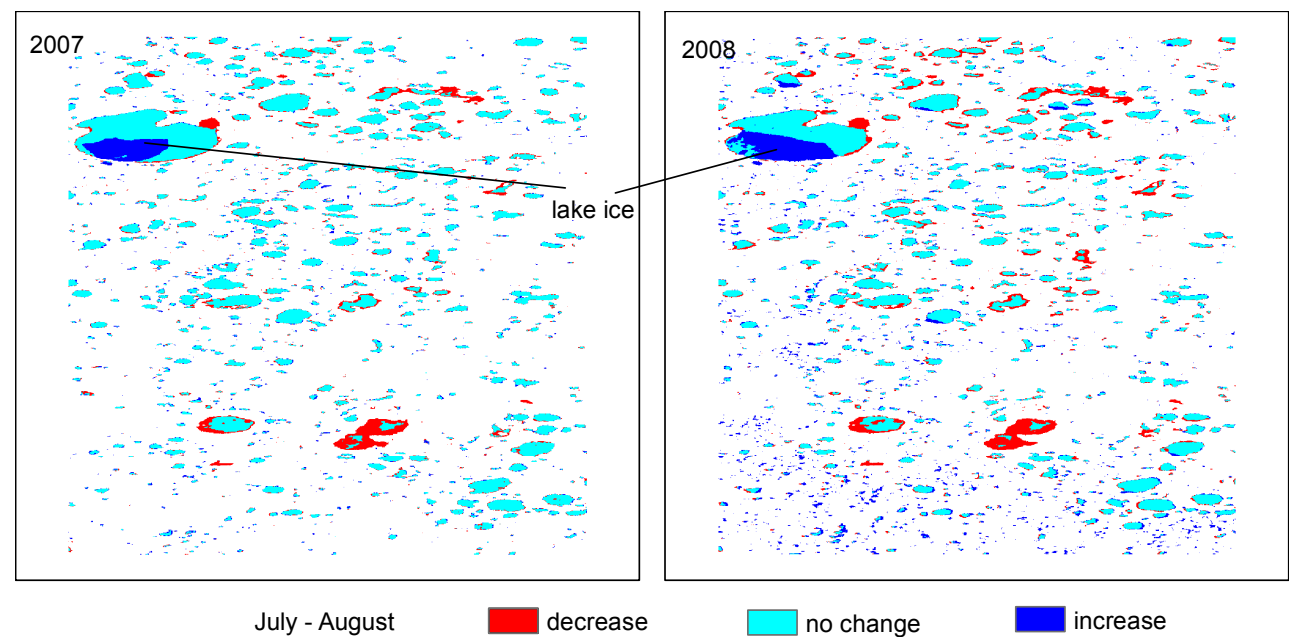

Fig. 5. Example for seasonal changes of open water extent in tundra (within a 0.5 degree cell): left - 7 July 2007 to 28 August 2007 , right 6 July 2008 to 21 August 2008.
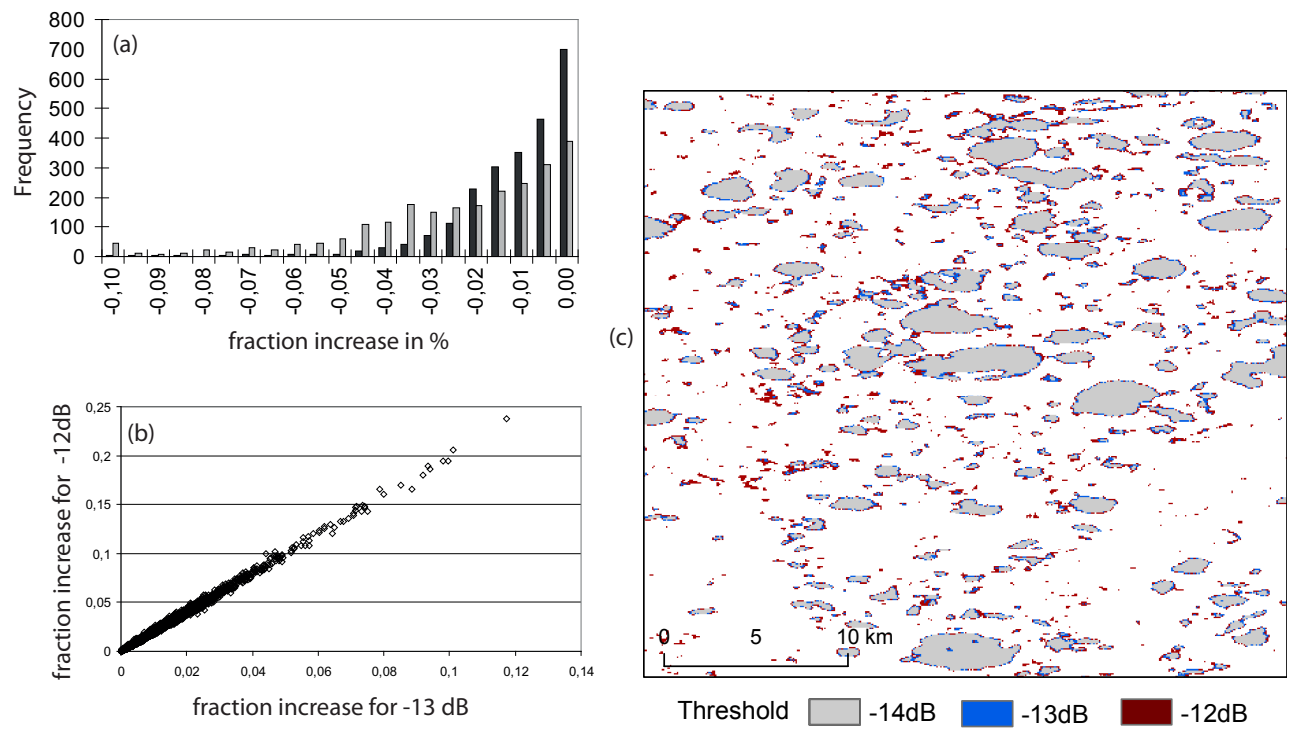

Fig. 6. Differences of water fraction between different thresholds: (a) histogram with black $-1 \mathrm{~dB}$ increase, grey $-2 \mathrm{~dB}$ increase, (b) scatterplot of fraction difference in comparison with a $-14 \mathrm{~dB}$ threshold and (c) example of classification results differences in tundra.

the MAMAP instrument. They defined an accumulation distance over which the emissions from diffuse sources (such as wetlands) would need to be integrated to give a measurable change in the atmospheric $\mathrm{CH}_{4}$ column. They derived a value of $86 \mathrm{~km}$ for a strong summertime emission flux from wetlands of $200 \mathrm{mgCH}_{4} \mathrm{~m}^{-2} \mathrm{~d}^{-1}$. Thus the sensitivity of satellite measurements of atmospheric methane concentration would not impose a tight constraint on the required accuracy of a wetland or inundation product. SAR based measurements could however indicate possible biases from under/overestimation of the wetland extent.
Data on wetland and inundation extent are also important in relation to the thawing of permafrost in a warming climate. Permafrost, defined as ground (soil or rock) that remains at or below $0{ }^{\circ} \mathrm{C}$ for at least two consecutive years, accounts for approximately $22 \%$ of the exposed land area in the Northern Hemisphere and is globally a significant store of organic carbon (Schuur et al., 2008). O'Connor et al. (2010) considered the water saturation status of the thawing permafrost to be the most important factor in determining whether the release of the frozen carbon occurred as $\mathrm{CO}_{2}$ or $\mathrm{CH}_{4}$. Depending on the conditions, thawing may lead to enhanced soil drainage 

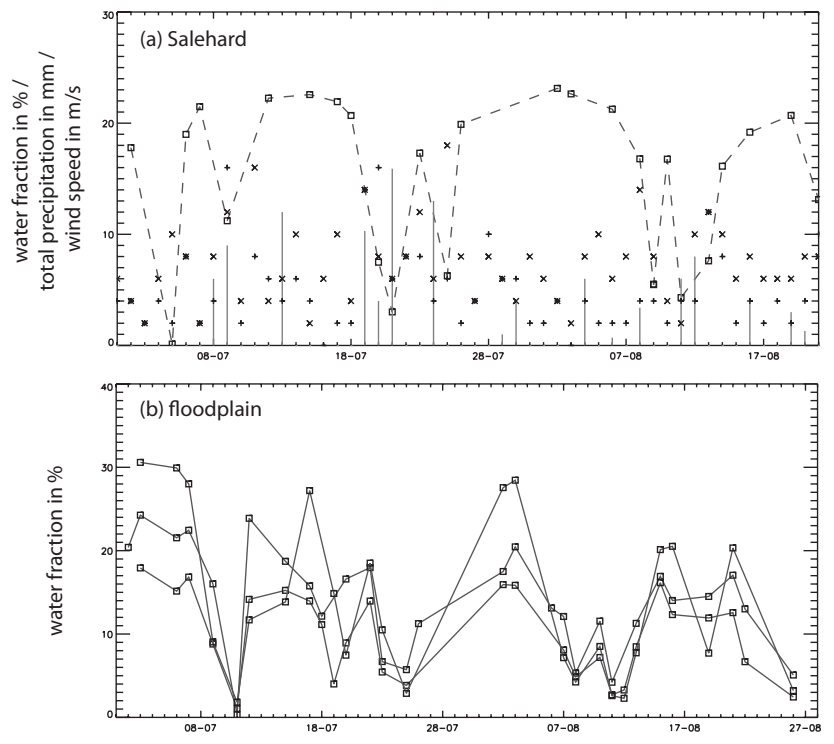

Fig. 7. Variation of water fraction from ASAR WS in summer 2007 in cells with on average at least $10 \%$ water: (a) the region of Salehard in \% (squares), wind speed from meteorological data $(+=$ 06:00 a.m., $\times=03: 00$ p.m.) in $\mathrm{ms}^{-1}$, total daily precipitation in $\mathrm{mm}$ (vertical bars) (b) cells of the floodplain $\left(66-67^{\circ} \mathrm{N}\right)$.
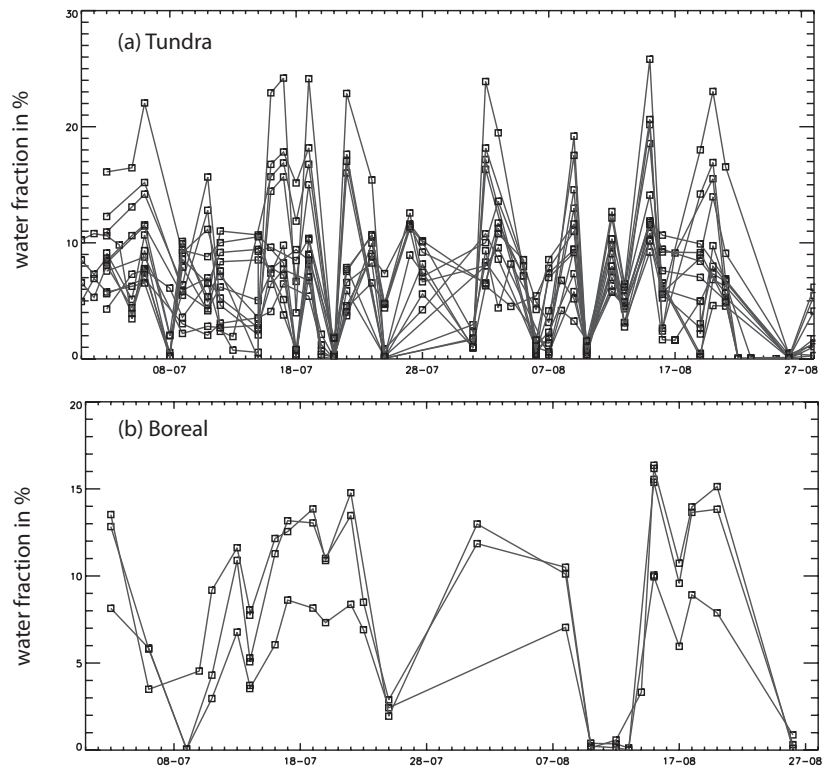

Fig. 8. Variation of water fraction from ASAR WS in summer 2007 in cells with on average at least $10 \%$ water: (a) all cells north of $67^{\circ} \mathrm{N}$, (b) all cells south of $66^{\circ} \mathrm{N}$.

and therefore a lowering of the water table (i.e. more $\mathrm{CO}_{2}$ ), or the opposite, whereby landscape collapse leads to impeded drainage and a raised water table (i.e. more $\mathrm{CH}_{4}$ ). The evolution of areas of saturation also exerts a strong control on the exchanges of heat and moisture between the land surface and the atmosphere, which are of critical importance to land surface and climate models. Thus there are several areas of land surface modelling that require information about the extent and characteristics of inundation, such as were derived in this study from SAR data.

\section{Conclusions}

The major known problems for application of SAR data for inundation monitoring are data availability and the wavelengths used. A series of European satellites (ERS, ENVISAT and the upcoming Sentinel 1) have SAR instruments operating in C-band. The suitability of data acquired at this wavelength is limited by the sensitivity to roughness changes of water surfaces. The major advantages over L-band sensors are the improved coverage and continuity, which are important for monitoring purposes. A region with relatively good data availability and with important inundation features was chosen in order to investigate these constraints further. In particular, the issues of the classification method and the impact of weather phenomena have been studied.

Although SAR data are independent of cloudiness and daylight availability, meteorology has a significant effect for this kind of application. On average, more than $60 \%$ of the data are affected by wind and rain in the tundra and taiga areas of Western Siberia. Detection results cannot be used on a single day basis. Update intervals need to be selected taking account of the possible persistence of rainy and windy weather conditions and the actual sampling interval. A minimum of 10 days is suggested for the Western Siberia region for the summer periods 2007 and 2008. This is still a shorter interval than in satellite data products that have been used previously in climate model studies (Ringeval et al., 2010, 2011; Riley et al., 2011).

The classification method is robust when the water class can be separated from other land cover. A universal threshold can be used so long as the bimodal backscatter distribution is maintained. Variations in the threshold do not significantly impact the resulting water fraction. The increase is less than $1 \%$ and the locations that are affected are mainly lake rims.

Quantification of any long-term (e.g. multi-year) trends in inundation requires that seasonal dynamics be accounted for, for example through the use of maximum inundation extent within each interval. Seasonal changes can be also observed outside of the $\mathrm{Ob}$ river floodplain in the boreal and tundra biome but at a much lower level. There are single lakes which drain and refill especially in tundra regions where seasonal overflowing of thermokarst lakes occurs. This seasonal behaviour needs to be considered when remotely sensed data are used for analyses of thermokarst as part of permafrost monitoring schemes.

Coarse scale products (such as Prigent et al., 2007) do not distinguish between flooded vegetation or open water. C-band SAR data can be utilized to separate these inundation types. This suggests that in future the combined use of such complementary data types might offer the best 

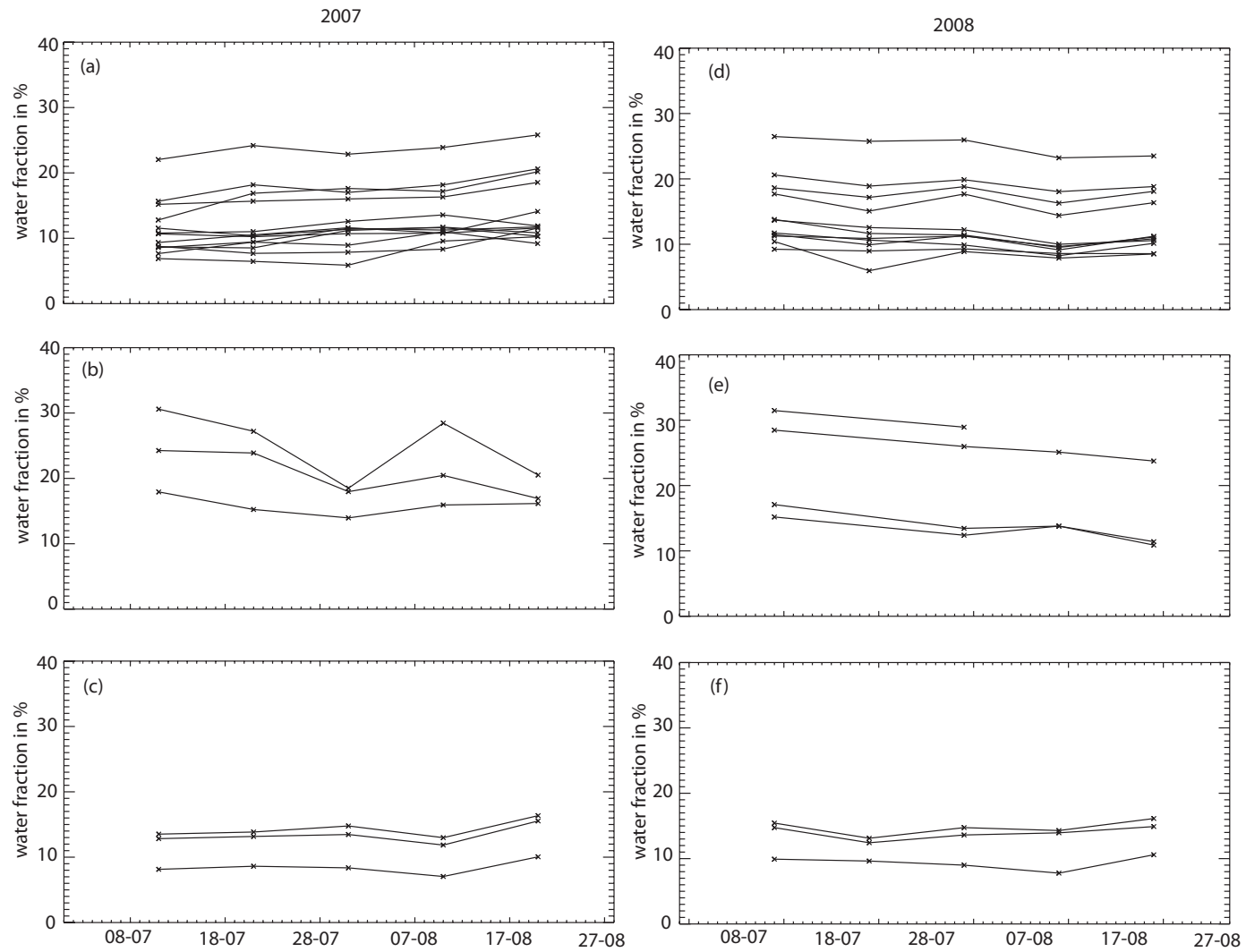

Fig. 9. 10 day maximum water fraction of grid cells with overall maximum $>10 \%$ water fraction from ASAR Wide Swath in summer 2007 for (a) all cells north of $67^{\circ} \mathrm{N}$, Tundra, (b) cells of the floodplain, (c) all cells south of $66^{\circ} \mathrm{N}$, Taiga/boreal; (d-f) 2008, respectively.

characterisation of wetlands and inundation. Parameters such as wetland structure (e.g. fragmentation, tundra pond density (Bartsch et al., 2008)), which are of interest for ecological applications are also retrievable.

The effects of wetland and inundation features on fluxes into the atmosphere generally occur at scales much smaller than those of a typical model grid box and as such have to be parameterised. The development and testing of model parameterisations, and the long-term monitoring of these changes in the environment, require information about the sub-grid scale distribution of wetlands and inundation over large areas, which is exactly the sort of information that a SAR product could provide. As part of the space component of the Global Monitoring for Environment and Security (GMES) programme, the European Union and the European Space Agency are preparing the next generation of imaging Synthetic Aperture Radars (SARs): the Sentinel-1 mission. The Sentinel-1 satellites will provide all-weather, day-andnight observations (Attema et al., 2007). In order to fullfil user requirements for operationally sustainable services, the mission is based - in contrast to the ERS-1, ERS-2 and ENVISAT missions - upon an operational concept (Attema, 2005). This would allow for frequent mapping of inundation dynamics.
Acknowledgements. This study was carried out as part of the ALANIS-Methane project, which is funded by the European Space Agency (ESA) Support to Science Element (STSE) program (ESRIN Contr. No. 4000100647/10/I-LG) and co-ordinated by $\mathrm{CEH}$, UK. It is also part of the PERMAFROST project, which is funded by ESA's Data User Element (DUE) program as a component of the Earth Observation Envelope Program (EOEP) (ESRIN Contr. No. 22185/09/I-OL) and co-ordinated by TU Wien. A. Bartsch is a recipient of a fellowship by the Austrian Science Fund (V150-N21).

Edited by: M. Marconcini

\section{References}

Attema, E.: Mission Requirement Document for the European Radar Observatory Sentinel-1 (Mission Requirement Specification), European Space Agency, 2005.

Attema, E., Bargellini, P., Edwards, P., Levrini, G., Lokas, S., and Moeller, L.: Sentinel-1 - the radar mission for GMES operational land and sea services, ESA Bulletin, 131, 10-17, 2007.

Bartsch, A.: Ten Years of SeaWinds on QuikSCAT for Snow Applications, Remote Sensing, 2, 1142-1156, 2010.

Bartsch, A., Pathe, C., Wagner, W., and Scipal, K.: Detection of Permanent Open Water Surfaces in Central Siberia with EN- 
VISAT ASAR Wide Swath Data with Special Emphasis on the Estimation of Methane Fluxes from Tundra Wetlands, Hydrol. Res., 39, 89-100, 2008.

Bartsch, A., Wagner, W., Scipal, K., Pathe, C., Sabel, D., and Wolski, P.: Global Monitoring of Wetlands - the Value of ENVISAT ASAR Global Mode, J. Environ. Manage., 90, 2226-2233, 2009.

Best, M. J., Pryor, M., Clark, D. B., Rooney, G. G., Essery, R .L. H., Ménard, C. B., Edwards, J. M., Hendry, M. A., Porson, A., Gedney, N., Mercado, L. M., Sitch, S., Blyth, E., Boucher, O., Cox, P. M., Grimmond, C. S. B., and Harding, R. J.: The Joint UK Land Environment Simulator (JULES), model description Part 1: Energy and water fluxes, Geosci. Model Dev., 4, 677699, doi:10.5194/gmd-4-677-2011, 2011.

Clark, D. B., Mercado, L. M., Sitch, S., Jones, C. D., Gedney, N., Best, M. J., Pryor, M., Rooney, G. G., Essery, R. L. H., Blyth, E., Boucher, O., Harding, R. J., Huntingford, C., and Cox, P. M.: The Joint UK Land Environment Simulator (JULES), Model description - Part 2: Carbon fluxes and vegetation, Geosci. Model Dev., 4, 701-722, doi:10.5194/gmd-4-701-2011, 2011.

Dadson, S. J., Ashpole, I., Harris, P., Davies, H., Clark, D., Blyth, E., and Taylor, C.: Wetland inundation dynamics in a model of land surface climate: Evaluation in the Niger inland delta region, J. Geophys. Res., 115, D23114, doi:10.1029/2010JD014474, 2010.

Davidson, N. C. and Finlayson, C. M.: Earth Observation for wetland inventory, assessment and monitoring, Aquatic Conservation: Marine and Freshwater Ecosystems, 17, 219-228, 2007.

Denman, K. L., Brasseur, G., Chidthaisong, A., Ciais, P., Cox, P., Dickinson, R., Hauglustaine, D., Heinze, C., Holland, E., Jacob, D., Lohmann, U., Ramachandran, S., da Silva Dias, P., Wofsy, S., and Zhang, X.: Couplings Between Changes in the Climate System and Biogeochemistry, in: Climate Change 2007: The Physical Science Basis. Contribution of Working Group I to the Fourth Assessment Report of the Intergovernmental Panel on Climate Change, edited by: Solomon, S., Qin, D., Manning, M., Chen, Z., Marquis, M., Averyt, K., Tignor, M., and Miller, H., Cambridge University Press, Cambridge, United Kingdom and New York, NY, USA, 2007.

Duguay, C. R., Pultz, T. J., Lafleur, P. M., and Drai, D.: RADARSAT Backscatter Characteristics of Ice Growing on Shallow Sub-Arctic Lakes, Churchill, Manitoba, Canada, Hydrol. Process., 16, 1631-1644, 2002.

Frey, K. and Smith, L. C.: How Well Do We Know Northern Land Cover? Comparison of Four Global Vegetation and Wetland Products with a New Ground-Truth Database for West Siberia, Global Biogeochem. Cy., 21, GB1016, doi:10.1029/2006GB002706, 2007.

Gedney, N., Cox, P. M., and Huntingford, C.: Climate feedback from wetland methane emissions, Geophys. Res. Lett., 31, L20503, doi:10.1029/2004GL020919, 2004.

Gerilowski, K., Tretner, A., Krings, T., Buchwitz, M., Bertagnolio, P. P., Belemezov, F., Erzinger, J., Burrows, J. P., and Bovensmann, H.: MAMAP - a new spectrometer system for columnaveraged methane and carbon dioxide observations from aircraft: instrument description and performance analysis, Atmos. Meas. Tech., 4, 215-243, doi:10.5194/amt-4-215-2011, 2011.

Hodson, E. L., Poulter, B., Zimmermann, N. E., Prigent, C., and Kaplan, J. O.: The El Niño - Southern Oscillation and wetland methane interannual variability, Geophys. Res. Lett., 38,
L08810, doi:10.1029/2011GL046861, 2011.

Keddy, P. A. and Fraser, L. H.: The World's Largest Wetlands: Ecology and Conservation, chap. Introduction: big is beautiful, Cambridge University Press, 1-10, 2005.

Lehner, B. and Döll, P.: Development and Validation of a Global Database of Lakes, Reservoirs and Wetlands, J. Hydrol., 296, 122, 2004.

Matgen, P., Hostache, R., Schumann, G., Pfister, L., Hoffmann, L., and Savenije, H.: Towards an automated SAR-based flood monitoring system: Lessons learned from two case studies, Phys. Chem. Earth, 36, 241-252, 2011.

Matthews, E. and Fung, I.: Methane Emission from Natural Wetlands: Global Distribution, Area, and Environmental Characteristics of Sources, Global Biochem. Cy., 1, 61-86, 1987.

Mikaloff Fletcher, S. E., Tans, P. P., Bruhwiler, L. M., Miller, J. B., and Heimann, $\mathrm{M} . \mathrm{CH}_{4}$ sources estimated from atmospheric observations of $\mathrm{CH}_{4}$ and its ${ }^{13} \mathrm{C} /{ }^{12} \mathrm{C}$ isotopic ratios: 1 . Inverse modelling of source processes, Global Biogeochem. Cy., 18, GB4004, doi:10.1029/2004GB002223, 2004.

O'Connor, F. M., Boucher, Gedney, N., Jones, C. D., Folberth, G. A., Coppell, R., Friedlingstein, P., Collins, W., Chappellaz, J., Ridley, J., and Johnson, C. E.: The possible role of wetlands, permafrost and methane hydrates in the methane cycle under future climate change: A review, Rev. Geophys., 48, RG4005, doi:10.1029/2010RG000326, 2010.

Papa, F., Prigent, C., and Rossow, W. B.: Monitoring Flood and Discharge Variations in the Large Siberian Rivers From a MultiSatellite Technique, Surv. Geophys., 29, 297-317, 2008.

Petrescu, A., van Beek, L., van Huissteden, J., Prigent, C., Sachs, T., Corradi, C. A. R., Parmentier, F. J. W., and Dolman, A. J.: Modeling regional to global $\mathrm{CH} 4$ emissions of boreal and arctic wetlands, Global Biogeochem. Cy., 24, GB4009, doi:10.1029/2009GB003610, 2010.

Prigent, C., Matthews, E., Aires, F., and Rossow, W. B.: Remote Sensing of Global Wetland Dynamics with Multiple Satellite Data Sets, Geophys. Res. Lett., 28, 4631-4634, 2001.

Prigent, C., Papa, F., Aires, F., Rossow, W. B., and Matthews, E.: Global Inundation Dynamics Inferred from Multiple Satellite Observations, 1993-2000, J. Geophys. Res., 112, D12107, doi:10.1029/2006JD007847, 2007.

Riley, W. J., Subin, Z. M., Lawrence, D. M., Swenson, S. C., Torn, M. S., Meng, L., Mahowald, N. M., and Hess, P.: Barriers to predicting changes in global terrestrial methane fluxes: analyses using CLM4Me, a methane biogeochemistry model integrated in CESM, Biogeosciences, 8, 1925-1953, doi:10.5194/bg-8-19252011, 2011.

Ringeval, B., de Noblet-Ducoudre, N., Ciais, P., Bousquet, P., Prigent, C., Papa, F., and Rossow, W. B.: An Attempt to Quantify the Impact of Changes in Wetland Extent on Methane Emissions on the Seasonal and Interannual Time Scales, Global Biogeochem. Cy., 24, GB2003, doi:10.1029/2008GB003354, 2010.

Ringeval, B., Friedlingstein, P., Koven, C., Ciais, P., de NobletDucoudré, N., Decharme, B., and Cadule, P.: Climate$\mathrm{CH}_{4}$ feedback from wetlands and its interaction with the climate- $\mathrm{CO}_{2}$ feedback, Biogeosciences Discuss., 8, 3203-3251, doi:10.5194/bgd-8-3203-2011, 2011.

Sabel, D., Bartalis, Z., Wagner, W., Doubkova, M., and Klein, J.P.: Development of a Global Backscatter Model in support to the Sentinel-1 mission design, Remote Sens. Environ., in press., 
doi:10.1016/j.rse.2011.09.028, 2011.

Schneising, O., Buchwitz, M., Reuter, M., Heymann, J., Bovensmann, H., and Burrows, J. P.: Long-term analysis of carbon dioxide and methane column-averaged mole fractions retrieved from SCIAMACHY, Atmos. Chem. Phys., 11, 2863 2880, doi:10.5194/acp-11-2863-2011, 2011.

Schroeder, R., Rawlins, M. A., McDonald, K. C., Podest, E., Zimmermann, R., and Kueppers, M.: Satellite microwave remote sensing of North Eurasian inundation dynamics: development of coarse-resolution products and comparison with high-resolution synthetic aperture radar data, Environ. Res. Lett., 5, 015003, doi:10.1088/1748-9326/5/1/015003, 2010.

Schuur, E., Bockheim, J., Canadell, J., Euskirchen, E., Field, C. B., Goryachkin, S. V., Hagemann, S., Kuhry, P., Lafleur, P., Lee, H., Mazhitova, G., Nelson, F. E., Rinke, A., Romanovsky, V., Shiklomanov, N., Tarnocai, C., Venevsky, S., Vogel, J. G., and Zimov, S. A.: Vulnerability of permafrost carbon to climate change: Implications for the global carbon cycle, BioScience, 58, 701-714, 2008.

Smith, L. C., MacDonald, G. M., Velichko, A. A., Beilman, D. W., Borisova, O. K., Frey, K. E., Kremenetski, K. V., and Sheng, Y.: Siberian Peatlands a Net Carbon Sink and Global Methane Source Since the Eearly Holocene, Science, 303, 353-356, 2004.
Walter, B. P., Heimann, M., and Matthews, E.: Modeling modern methane emissions from natural wetlands 1 . Model description and results, J. Geophys. Res., 106, 34189-34206, 2001.

Wania, R., Ross, I., and Prentice, I.: Integrating peatlands and permafrost into a dynamic global vegetation model: 1. Evaluation and sensitivity of physical land surface processes, Global Biogeochem. Cy., 23, GB3014, doi:10.1029/2008GB003412, 2009a.

Wania, R., Ross, I., and Prentice, I. C.: Integrating peatlands and permafrost into a dynamic global vegetation model: 2. Evaluation and sensitivity of vegetation and carbon cycle processes, Global Biogeochem. Cy., 23, GB3015, doi:10.1029/2008GB003413, 2009b.

Whitcomb, J., Moghaddam, M., McDonald, K., Kellndorfer, J., and Podest, E.: Mapping vegetated wetlands of Alaska using L-band radar satellite imagery, Can. J. Remote Sens., 35, 54-72, 2009.

Wuebbles, D. J. and Hayhoe, K.: Atmospheric methane and global change, Earth Sci. Rev., 57, 177-210, 2002. 